2020, Volume 14, International Conference Innovative Business Management \& Global Entrepreneurship (IBMAGE 2020), pages: 627-639 |

https://doi.org/10.18662/lumproc/ibmage2020/45

\section{Internal Audit} versus Internal

\section{Control - Tools for}

Evaluating the

Internal

Management System at the level of local public entities

\section{Nicoleta ARDELEANU ('TRIFU) ${ }^{1 *}$}

${ }^{1}$ Valahia University of Târgoviste, Târgoviste, Romania, nico75ard@yahoo.com.

* Corresponding author.
Abstract: This study presents the role of internal public audit organized at the level of local public administration, the interdependence between internal audit and internal control as well as the specific ways of evaluating the management system and internal managerial control. The erroneous perception of the specific objectives of the internal public audit has often led to a reluctance on the part of the decision makers. Misunderstanding the role of internal audit is a major risk in the functioning of the decision-making system. The internal audit recommendations give assurance to the general management through the periodic evaluation of the main functional systems: the financialaccounting system, the public procurement system, the decisionmaking system and especially the management and internal managerial control system.

Keywords: Internal Audit, Internal Audit Function, Risk Management

How to cite: Ardeleanu (Trifu), N. (2020). Internal Audit versus Internal Control - Tools for Evaluating the Internal Management System at the level of local public entities. In M. W. Staniewski, V. Vasile, \& A. Grigorescu (vol. ed.), Lumen Proceedings: Vol. 14. International Conference Innovative Business Management \& Global Entrepreneurship (IBMAGE 2020) (pp. 627-639). Iasi, Romania: LUMEN Publishing House. https://doi.org/10.18662/lumproc/ibmage2020/45 


\section{Introduction}

In order to carry out the research it is necessary to examine the internal audit from the perspective of positioning as a function, in relation to another similar function - internal/managerial control.

The form of organization of the internal audit is influenced and depends to a large extent on the possibilities of the public entity to bear the costs of this function, the size and complexity of the activities/ processes/ operations, as well as the degree of centralization-decentralization of the internal audit.

\section{The Connection between Internal Audit and Internal/ Managerial Control}

The development and implementation of the internal/managerial control system is the responsibility of the management of each public entity and must be based on the requirements and references established by the internal control standards adopted.

Internal/managerial control is the instrument by which the management of the public entity, through the report drawn up, provides assurance to all stakeholders regarding the achievement of the objectives under conditions of economy, efficiency, effectiveness and regularity and ensures at the same time that the financial statements reflect reality and the true image.

From the analysis of the general objective of the internal public audit it was found that this is a function of assistance to the management organized in order to help him better manage his activities.

A characteristic of the current practice is the fact that the definition of internal/managerial control has created certain confusions, within some public entities the internal control being included in the internal public audit structure. In these circumstances, the tasks specific to internal public audit and internal control were carried out by the same organisational structure, thus limiting the independence and objectivity of the internal audit, especially when one of the main objectives of the internal audit is the evaluation of the internal control system [10].

\section{Aim of the research}

This study presents the role of internal public audit organized at the level of local public administration, interdependence between internal audit and internal control as well as the specific ways of evaluating the management system and internal management control. 
The misperception of the specific objectives of the internal public audit has often led to a reluctance on the part of decision-makers [7; 9].

Misunderstanding the role of internal audit is a major risk in the functioning of the decision-making system. The recommendations of the internal audit give assurance to the general management by periodically evaluating the main functional systems: the financial-accounting system, the public procurement system, the decision-making system and especially the management system and internal management control.

\section{Research Methods}

In the elaboration of this research we started from theory, applying a deductive type research, in order to reach individual conclusions regarding the improvement of the internal audit, but also an inductive type research, starting from particular judgments to the formulation of general conclusions, by verifying the transposition in practice of the information obtained.

In order to achieve the objectives proposed in this scientific approach, the methodology used was based on: theoretical research, inspired by the following sources: international internal audit standards, specialized books, studies and articles published in renowned journals recognized nationally and internationally, and empirical research, by applying research methods to verify the research hypotheses and establish their own general conclusions.

The conclusions of the theoretical and empirical research that contributed to the argumentation of the improvement of the internal audit and the increase of its efficiency at the level of the entities.

In elaborating this study, I took into account the theoretical and practical research of some specialists who expressed their opinion on the concept of internal audit, organization and operation of internal audit.

This theme is supported by my own activity as an internal auditor for over 17 years.

\section{The Evaluation of Concepts of Internal/Managerial Control and Internal Public Audit}

\subsection{Design and development of internal / managerial control}

The internal control is a dynamic process with responsibility: protecting the entity's property and preventing and detecting errors, fraud, loss, abuse and ineffective management [12]. In other words, the internal control system aims to ensure that the activities or processes carried out within the public entity are carried out in accordance with the laws, 
regulations or instructions in force, without being ensured and quality elements.

By design and developing of the internal/managerial control system, the focus has been on ensuring the achievement of the entity's objectives in conditions of efficiency and effectiveness. At the same time, the responsibility for creating and ensuring the functionality of the internal/managerial control system, effectively, is the management of the public entity.

By implementing this concept in Romanian practice, a new type of management has been imposed in public entities, characterized by increased managerial responsibility and implementation of internal/managerial control standards. The internal/managerial control system includes the proper and effective exercise of all management functions, being in fact an art of management and covering all aspects of an organization [11].

Management, which is responsible for the implementation of the internal/managerial control system, must use this specific management tool to achieve the objectives set and not as a control function. Management must also understand and overcome at the same time the tendency to avoid internal/managerial control, because avoiding the identification of the reporting of deficiencies and difficulties faced by the public entity does nothing but aggravate problems and their consequences.

By implementing on the 16 internal control standards, each functional structure of the public entity ensures a control environment, a system of performance measurement and risk management, an information and communication system, appropriate and appropriate control and evaluation activities, which enable it to achieve its objectives set in conditions of efficiency and effectiveness.

Internal/managerial control is a process of measuring performance, initiating and undertaking actions, exercising it serving the management of the organization. The need for an efficient internal control system at the entity level results from the limited nature of material and monetary resources. In this respect, the main role of control to economic entities is to follow the legal provisions on how to spend money.

Viewed through different ways, internal control is considered:

- management function - by this each manager wants to ensure that the activity is carried out according to the predetermined schedule, that the resources are used according to the intended destination and that, in the end, the actual performance will achieve or exceed the objectives initially set [6]; 
- $\quad$ attribute of leadership - means of improving the activity of economic entities, exercised in different forms of structures organized vertically, with responsibilities and objectives clearly specified by law;

- tool to verify how resources are managed - It refers to the way in which funds are set up in the economy, their allocation to beneficiaries and the efficiency with which the entities use the resources at their disposal, whether they are their own or from the state budget.

Internal control standards have a general form that was necessary to allow managers to customize them according to the legal specifics of each economic entity. Management is constantly concerned about the internal control system due to the evolution of the risks identified in the economic entity [3]. The reorganization of the internal control system in an economic entity is the responsibility of general management. According to good practice, internal control exists in the course of each activity being formalised by operational working procedures, with the responsibility contained in the job descriptions, accompanied by instructions for carrying out those activities to which the internal control activities are attached. The manager sets up functions, programs, for each activity, designed to limit and maintain the associated risks within the limits of the risk appetite accepted by the organization.

\subsection{Internal public audit - reference framework, scope of activity}

The internal audit has developed progressively within local public entities, so that the scope of activity of the internal public audit division currently contains all the activities carried out, as approved in Law no. 672/2002 [7] on internal public audit:

- financial or financial activities with financial implications carried out by the public entity from the time of the creation of the commitments until the use of the funds, including repayable or nonrefundable external funds;

- the establishment of public revenue, the authorisation and establishment of debt securities and the facilities granted when they are collected;

- the administration of public assets, as well as the sale, pledge, concession or rental of property in the private or public domain of the state or administrative-territorial units;

- $\quad$ financial management and control systems, including accounting and information systems. It is noted from the above that the scope of the 
internal audit includes all the activities and control systems attached to them at all levels, including those areas arising from contractual commitments.

Taking into account the scope of the internal audit, within local public entities, the objectives of the internal audit are:

- $\quad$ reasonable assurance and management advice to improve the entity's systems and activities;

- $\quad$ supporting entity management in achieving objectives by systematically and methodically addressing and evaluating processes related to risk management, internal control and governance.

The internal public audit structure carries out its tasks by respecting the principles of legality, economy, efficiency and effectiveness. To this end, it shall establish and develop a specific reference framework with the aim of making the internal audit function aware, but also of planning and carrying out internal public audit missions.

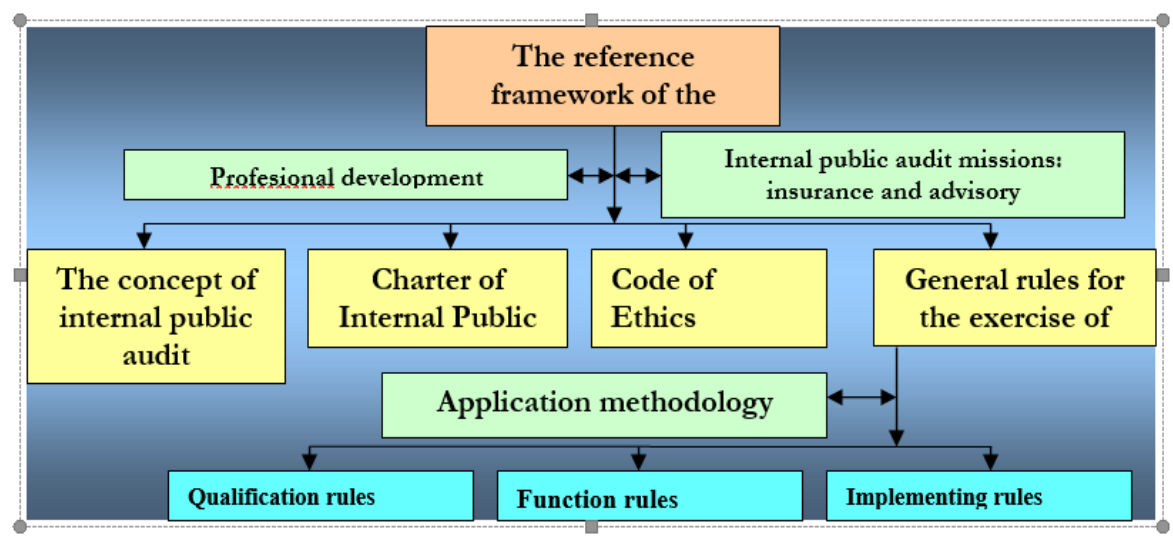

Figure 1. - The reference framework of the internal public audit

Source: Own projection

The research shows that the elements of the reference framework of public internal audit consist of the two major areas directly related: professional development and exercise of public internal audit missions: insurance and counseling:

- $\quad$ the concept of public internal audit, according to which the internal audit performs insurance and advisory missions, the purpose being to bring added value to the entity;

- $\quad$ internal audit charter. - document prepared by the internal audit department and approved by the management, which establishes the 
mission, competence and responsibilities of the internal audit, the purpose and scope of the internal audit, the position of the internal audit structure within the public entity, methodology and types of audit, the rules of ethical conduct, the rights and obligations of internal auditors, authorize access to data, information and other physical assets of the audited structure;

- the code of ethics presents the principles and values that guide the professional practice of internal auditors. This is a statement of the values and principles that should guide the day-to-day work and practice of internal auditors [1]. At the same time, it defines a set of principles and rules of conduct [8] that govern the work of internal auditors as shown in the following figure:

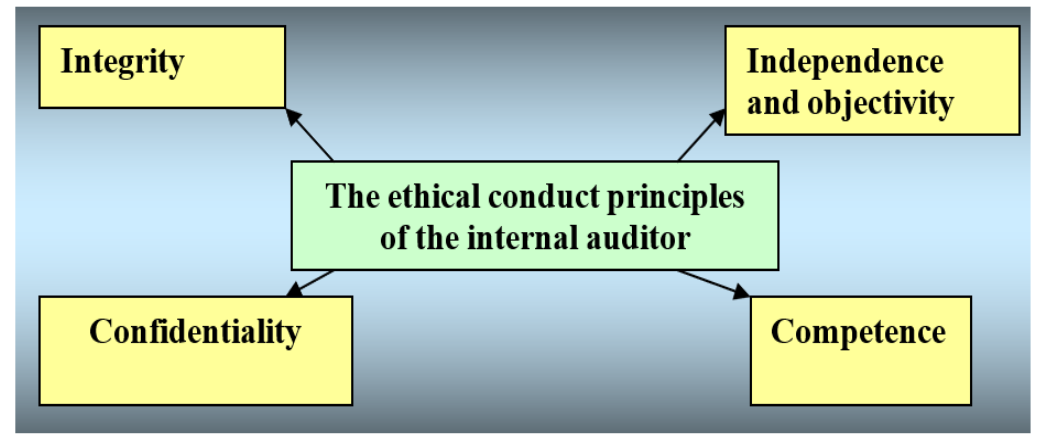

Figure 2. - The ethical principles of public internal audit

Source: Own projection

The established rules of ethical conduct represent norms of behavior for the internal auditors, obligatory to be observed in the accomplishment of the attributions.

In practice, in some situations internal auditors are required to assume responsibilities within the entity, situations in which the principle of independence is no longer ensured. It should also be borne in mind that internal auditors are employees of the public entity, which creates a certain state of dependence on the management of the entity. Under these conditions, integrity and objectivity will have to be the intrinsic elements of the professionalism of internal auditors. 


\subsection{Analyzing the concepts, currently recognized and applied in the Romanian public system}

Since 1999, in Romania, "internal control and internal audit" is introduced for economic entities in the public sector $[4 ; 5]$.

In the research we carry out, there is a need for clarifications on the concepts and practice in this sector of activity [2], Table 1.

These functions have both elements that approach them and elements that differentiate them. The development and implementation of an internal/managerial control system not only involves concrete control activities, but includes all management functions and covers all aspects of the entity.

The scope of internal/managerial control is to ensure the management of funds in an economic, efficient and effective manner, and the scope of internal public audit is to assess and improve the efficiency and effectiveness of risk management, control and governance processes.

Compared to the initial definition given to internal/managerial control, it is found that it was amended in 2003, following the amendment and completion of O.G. no.119/1999 [6].

Table 1. Comparative situation Internal Audit versus Internal Control

\begin{tabular}{|c|c|}
\hline INTERNAL AUDIT & INTERNAL CONTROL \\
\hline Independent structure & Integrated into the organization \\
\hline Planned mission & Continuous process \\
\hline Leadership function & $\begin{array}{l}\text { This function exists in every } \\
\text { activity }\end{array}$ \\
\hline Organized at the management level & Organized in each compartment \\
\hline $\begin{array}{l}\text { Obliged to report any malfunctions } \\
\text { in connection with internal control }\end{array}$ & $\begin{array}{l}\text { Elaboration of procedures to } \\
\text { eliminate risks }\end{array}$ \\
\hline $\begin{array}{l}\text { Helps the audited entity achieve its } \\
\text { goals }\end{array}$ & $\begin{array}{l}\text { Follows the application of the } \\
\text { procedures in practice }\end{array}$ \\
\hline Totally different from inspection & Similar to inspection \\
\hline $\begin{array}{l}\text { The auditor's recommendations, } \\
\text { based on expertise, can be } \\
\text { considered benefits for internal } \\
\text { control }\end{array}$ & $\begin{array}{l}\text { Those controlled accept the } \\
\text { findings }\end{array}$ \\
\hline $\begin{array}{l}\text { The auditor's recommendations are } \\
\text { optional }\end{array}$ & Control findings are mandatory \\
\hline $\begin{array}{l}\text { The entity must look at the internal } \\
\text { audit }\end{array}$ & Look at the whole organization \\
\hline
\end{tabular}

(Source: Own projection) 
The concept of internal/managerial control has evolved from a set of measures to a set of forms of control, which are no longer established by regulations, but are decided by the management of the public entity whether or not it implements them in its entirety. The concept of internal/managerial control also links both the objectives of the entity and the elements characteristic of performance: economics, efficiency and effectiveness.

From the research we deduce the idea that one of the important aspects of internal/managerial control is that it represents a managerial function with which management establishes and implements control devices on all activities and actions carried out in order to ensure that the objectives are achieved, at least at the planned level. The internal public audit is responsible for assessing the internal/managerial control system and to whether it is functioning properly and ensuring that the objectives are met. [3]. If it finds its insufficiency or deviations from the established rules, it shall analyse the causes which have led to them and shall order corrective measures or improvements in the appropriate activities.

\subsection{Analysis of the objectives pursued by the two functions within public entities}

From the research of the objectives set to internal/managerial control it is found that it meets the following requirements:

- $\quad$ is a tool created by management with the aim of providing assurance on the achievement of tasks/objectives in conditions of efficiency and effectiveness;

- $\quad$ preventing or limiting fraud and errors and alerting management to uncontrolled or under-controlled risks;

- $\quad$ ensuring the internal and external information flows necessary to carry out the activities, the reliability of financial reporting;

- $\quad$ concordance with the laws, regulations and instructions applicable to the entity and management decisions and the identification of deviations from them.

\subsection{Analysis of the two functions through the prism of the scope of action and how specific activities are delineated}

Internal/managerial control standards are a reference system, setting out a set of management rules to be implemented by all public entities.

The objective of the implementation of the standards is to create a uniform and coherent internal control system at the level of all public entities. 
Is necessary to specify that the organisation of internal control, on the basis of the concept of managerial responsibility [12], comply with the following conditions:

- the head of the public entity is responsible for the organization and operation, under optimal conditions, of the internal/managerial control system;

- the functional structure responsible for monitoring, coordinating and methodological guidance of the internal control system and the leaders of the functional structures of the entity are responsible for the implementation of the internal/managerial control system adopted at the entity level;

- implementation of the internal/managerial control system is ensured by implementing internal control standards adopted by national regulations, according to the requirements set by the entity's management;

- the efficiency and effectiveness of the system is ensured by monitoring the actions carried out at the level of each functional structure of the entity and monitoring the achievement of the objectives;

- the development of the internal/managerial control system is ensured by continuous adaptation to the development requirements of the entity.

In these circumstances, in the process of developing and implementing the internal/managerial control system, internal audit can play two roles.

- the first of these is manifested in the early stages of the implementation of the internal/managerial control system, when the internal audit must assist and cooperate the management of the entity and the persons responsible for implementation, in order to promote good practices and introduce specific policies, mechanisms and procedures, but without taking responsibility.

- $\quad$ secondly, the internal public audit assesses the internal/managerial control system and provides assurance of its compliance and performance.

\section{Discussions}

From the presented it is found that the public internal audit has the role of evaluating the internal / managerial control system and identifies the insufficiencies, dysfunctions and errors of the internal control devices 
implemented by the entity's management. Internal control devices include: objectives, means, information systems, organisation, procedures and supervision.

It follows that the internal public audit, although it is part of the internal/managerial control system, is not confused with it.

Between these two functions there are similarities but also differences, such as:

- both functions exist and manifest within the public entity, but the internal audit, although part of the internal/managerial control system, extends beyond it;

- the internal/managerial control system is found in all the functions performed and activities carried out within the public entity. It is part of the global system of processes and activities carried out by the public entity. The internal audit is organised separately within a compartment under the direct control of the leader, but the scope of investigation is extended to all activities carried out by the entity;

- the internal/managerial control system is an ongoing process, carried out by each employee, within the limits of the responsibilities and tasks established, while the internal audit is a planned process, carried out by specialists in the field, depending on the outcome of the risk assessment;

- internal public audit in order to achieve the general objective uses a number of specific audit tools, procedures, methods and techniques in order to assess and ensure the functionality of internal control, instead internal/managerial control involves the implementation of control devices for all activities carried out in the entity, with the aim of ensuring the functionality of internal control, limiting the level of risks and achieving objectives in conditions of efficiency and effectiveness;

- $\quad$ internal/managerial control develops strategies, policies, procedures to ensure the achievement of activities and objectives in conditions of efficiency and effectiveness, the internal public audit evaluates the implementation of the devices created by internal control and examines whether they prevent irregularities and lead to performance on the entity as a whole or on each activity carried out;

- the implementation of the internal/managerial control system shall be carried out on the basis of self-assessment carried out by the heads of functional structures and the report prepared by the management of the public entity, while the internal public audit shall draw up an audit report showing the problems tested, the findings 
made, the causes and consequences of the problems identified and the proposals for improving the activities;

- the report on the internal/managerial control system accompanies and guarantees the reality and fidelity of the financial statements.

- internal audit is useful for the existence of internal/managerial control, as it carries out a thorough assessment of it and makes an assessment giving management assurance that it works.

\section{Conclusions}

As a result of the research carried out, we consider that the task of the internal auditor is to discover the dysfunction, to carry out the research and then to report this issue to the management of the entity, with the proposal to arrange the necessary measures to establish the extent of the dysfunction and to apply the legal provisions. After reporting the malfunction, the auditor may continue his mission in accordance with the established procedure, assessing internal control processes that have not worked or have malfunctioned. Thus, the auditor will identify the causes that caused the dysfunction and make recommendations on what needs to be changed, added, and eliminated, so that in the future such a situation will not be reached.

As a consequence, it can be stated that internal audit, although part of the internal/managerial control system, is a distinct function necessary for management, which verifies the implementation of internal control standards and their degree of implementation allows achieving the entity's objectives in conditions of efficiency and effectiveness.

There is also a complementary, synergistic connection between the two functions; each function supporting the other with information, clues, signals of weaknesses retained during the implementation of the control or implementation of internal audit missions.

\section{References}

[1] Ghiță M, Croitoru I, Ţogoe D. Corporate governance and internal audit. Galați: Editura EuroPlus; 2010.

[2] Ghiță M, Sprânceană M. Internal audit. București: Editura Tribuna Economică; 2009.

[3] Ghiţă M. Internal audit. Bucureşti: Editura Economică; 2004.

[4] Government Ordinance no.119/1999 on internal audit and preventive financial control. [nternet]. Monitorul Oficial al României nr. 430/1999 
[Accessed Jul 2020]. Available from:

http://legislatie.just.ro/Public/DetaliiDocumentAfis/19169

[5] Government Ordinance no.119/1999 on internal control and preventiv financial control, republished. [Internet]. Monitorul Oficial al României nr. 799/2003 [Accessed Jul 2020]. Available from:

http://legislatie.just.ro/Public/DetaliiDocument/19169

[6] Ionescu Gh. Organizational management. Bucureşti: Editura Tribuna Economică; 2001.

[7] Law no. 672/2002 on internal public audit, republished. [Internet]. Monitorul Oficial al României nr. 856/05.12.2011 [Accessed Jul 2020]. Available from: http://legislatie.just.ro/Public/DetaliiDocumentAfis/40929

[8] Munteanu V, Zuca M, Zuca S. Internal audit of enterprises and public institutions. Bucureşti: Editura Wolters Kluwer; 2010.

[9] Order of the General Secretariat of the Government no. 600/2018 on the approval of the Code of Internal/Managerial Control of Public Entities. [Internet]. Monitorul Oficial al României nr. 387/07.05.2018 [Accessed Jul 2020]. Available from: http://legislatie.just.ro/Public/DetaliiDocument/200317

[10] Tabirca AI, Florin RA, Valentin RA. The Historical Evolution of Research in Accounting. National and European Context. Ecoforum Journal [Internet]. 2020 Jan 30 [cited 2020 Jul 11];9,1(21). Available from: http://www.ecoforumjournal.ro/index.php/eco/article/view/1070/657

[11] Tomoială M, Mare E. Internal/managerial control - Why? And how? Iaşi: Editura STEF; 2012.

[12] Vasile E, Popescu M. Internal Auditing Value Added Concept. Internal Auditing \& Risk Management. 2001. Annual VI, 2(22):57-64 